\title{
Análise Macroergonômica em uma Empresa da Construção Civil
}

\author{
Analysis Macroergonomic in a Civil Construction Company
}

\author{
SIMONI, Cássia Gisele \\ Especialista em Gestão do Design; UEL - Universidade Estadual de Londrina \\ gisimonicoda@hotmail.com
}

ZERBETTO, Cristiane A. de A.

Dra. Em Agronomia (Energia na Agricultura); UEL- Universidade Estadual de Londrina cra@uel.br

\begin{abstract}
Resumo
Com a modernidade busca-se a eficácia e o sucesso das organizações em um mercado cada vez mais competitivo. No entanto é necessário que haja um equilíbrio entre as habilidades dos funcionários em executar as tarefas e a demanda do mercado. A macroergonômia tem por objetivo contribuir para melhorar as condições de trabalho trazendo benefícios para as empresas obterem maior sucesso em seus produtos e serviços.
\end{abstract}

Palavras Chave: Macroergonomia; Gestão; Design.

\begin{abstract}
With modernity seeks the effectiveness and success of organizations in an increasingly competitive market. However there must be a balance between employee skills in performing the tasks and the market demand. The macroergonomics aims to contribute to improving working conditions with benefits for companies to achieve greater success in their products and services.
\end{abstract}

Keywords: Macroergonomic; Management; Design.

\section{Introdução}

No mercado atual a diversidade é um ponto favorável ao empresário e, neste sentido, um fator importante para o sucesso de uma empresa é a gestão do design como ferramenta estratégica, visando obter maior sucesso em seus produtos e serviços.

Segundo Martins (2008) a gestão do design é o conjunto de técnicas de gestão dirigido a maximizar, ao menor custo possível, a competitividade à empresa obtém pela incorporação e utilização do Design como instrumento de sua estratégia empresarial.

$\mathrm{Na}$ atualidade é observado um aumento progressivo da automação de sistema em empresas, o que sugere o uso da macroergonomia, que parte do princípio de avaliar a empresa de cima para baixo e usa como ferramenta a análise sociotécnica e o enfoque dos sistemas.

Tendo em vista o enfoque global e interdisciplinar da ergonomia Hendrick (1993) e Brown (1995) citam a macroergonomia, que estuda a adequação organizacional da empresa 
em detrimento às novas tecnologias de produção e métodos de organização de trabalho, a qual irá contribuir com a Gestão do Design, para se estabelecer um diagnóstico inicial.

Dentre os segmentos empresariais podemos destacar o setor da construção civil, o qual está em grande expansão, tendo importância na geração de empregos. Vale destacar que nunca foi tão alto o número de trabalhadores que atuam nessa área, tendo vagas para todo tipo de profissional, do pedreiro ao engenheiro. A construção civil destaca-se como um dos setores com altos índices de acidentes de trabalho, sendo assim, vê-se a necessidade de um estudo mais aprofundado deste setor, buscando melhorar as condições de trabalho dos funcionários, trazendo benefícios para empresa, a qual conseqüentemente deverá obter maior sucesso em seus produtos e serviços.

Com base nestes apontamentos o objetivo geral deste trabalho foi à aplicação do método da Análise Macroergonômica do Trabalho (AMT) em uma empresa de construção civil visando o aprimoramento desta e contribuindo para uma maior segurança e qualidade no trabalho dos operários. Para isto o trabalho se embasou nos seguintes objetivos específicos: levantamento do estado da arte dos temas correlacionados ao assunto; apreciação ergonômica através da imersão em uma primeira visita; aplicação da diagnose ergonômica para identificar os mais graves problemas dentro dos setores e atividades desenvolvidas, e por fim um plano de implementação para as propostas macroergonômicas na empresa.

A Análise Macroergonômica do Trabalho é aplicada para definir os pontos que servirão de base para estruturar toda a organização, buscando melhorar o desenvolvimento das atividades, gerando assim maior satisfação aos funcionários e, conseqüentemente, maior produtividade. Segundo lida (2005) a macroergonomia contribui para melhorar a eficiência, a confiabilidade e a qualidade das operações industriais por meio do aperfeiçoamento do sistema homem-máquina-ambiente, organização do trabalho e melhoria nas condições físicas do trabalho.

O estudo macroergonômico considera o levantamento de dados e análises das condições do ambiente físico e do posto de trabalho, dos fatores organizacionais e de relacionamento, os quais influenciam diretamente na rotina de trabalho, sendo determinantes na qualidade de vida do trabalhador.

Por meio da participação dos operários de diferentes áreas da empresa, pôde-se identificar os Itens de Demanda Ergonômica (IDE's), que compreenderam as manifestações destes quanto ao posto de trabalho e execução das tarefas, relacionamentos e aspectos organizacionais, aumentando assim a possibilidade do sucesso na implementação das modificações sugeridas a partir do método da Análise Macroergonômica do Trabalho (AMT).

Ao final do trabalho poderá ser observado o quanto este método pôde contribuir com a empresa analisada.

\section{Gestão do Design}

O mercado mundial está mudando com o aumento de produtos diferenciados, com a aplicação de novas tecnologias e novas formas de gerenciar. Essa realidade mostra que o diferencial está na inovação, utilizando o design como principal fator de competividade. Visto que as empresas concorrem globalmente, tanto as grandes como as pequenas, surgem produtos cada vez mais variados diferenciados pelo preço, qualidade, estilo e tecnologia utilizada e principalmente com valores agregados. 
Para que uma empresa torne-se competitiva neste mercado, esta deve atender as expectativas dos consumidores e surpriendê-los quanto aos seus produtos e serviços oferecidos, vendo o cliente não apenas como consumidor e sim como usuário. Esta é uma das funções básicas do design que atua como um processo contínuo na organização. De acordo com Magalhães (1997), o Design, como fator estratégico, é selecionado como instrumento para diferenciação competitiva, por ser um aliado para sublinhar uma empresa no mercado e garantir a diferença necessária à sua sobrevivência. A gestão do design gerencia as atividades de design delimitadas pela empresa com o objetivo de implantar a cultura empresarial na mudança de sua própria imagem.

A qualidade torna-se um fator importante quando o design faz parte da organização de acordo com Wolf (1998) considerando desta forma o custo, qualidade, impacto ambiental, adequação ergonômica (relação homem/máquina/ambiente), valor de uso (forma/função) buscando atender os desejos do consumidor e os objetivos da organização.

A gestão do design deve ser considerada no planejamento estratégico da empresa, buscando aperfeiçoar o processo projetual através de conjunto de atividades específicas voltadas aos objetivos da empresa. Segundo Gomes (2003), a gestão do design além de interferir na atividade projetual é responsável também pela implementação, manutenção e constante avaliação de tudo a que se refere à identidade corporativa da empresa.

A implantação da gestão do design na empresa traz mais competividade a este e, conseqüentemente, a colocação bem sucedida dos produtos e serviços no mercado.

A gestão do design caracteriza-se pela multidisciplinaridade e pela interação entre a concepção, a produção e a comercialização de um produto, visando atingir as necessidades, tanto do consumidor (usuário) como da organização, visando permitir à empresa estabelecer estratégias de condução do negócio dentro de um planejamento em longo prazo.

\section{Macroergonomia}

Como pôde ser observada no tópico anterior, a gestão do design é uma ferramenta poderosa a ser implantada nas empresas para estas obterem maior sucesso em seus produtos e serviços. Para isso a primeira medida é uma análise macroergonômica para avaliação das tarefas, trabalhos, produtos, ambientes e sistemas, de maneira a torná-los compatíveis com as necessidades, habilidades e limitações das pessoas inseridas no sistema (empresa) existente. A macroergonomia é uma das formas mais eficientes de conciliar as questões humanas de trabalho com as questões de sobrevivência da empresa no mundo atual (GUERIN et al., 2001). A macroergonomia é uma vertente cada vez mais difundida no meio empresarial para se obter diagnósticos precisos quanto aos problemas recorrentes da má organização do sistema de trabalho produtivo.

A ergonomia é uma ciência que visa melhorar as condições do trabalho humano, adequando o objeto às limitações humanas, de forma que seu operador não executasse nada além do projetado.

A ergonomia procura atender a demanda da produção e da gerência, e ao fazer isto acaba atendendo também às necessidades dos usuários (trabalhadores), gerando satisfação e sendo um fator alavancador de vendas. Aplicada tanto na concepção de projetos ou na correção de um sistema já existente, sua função esta em adequar o trabalho as capacidades físicas e cognitivas dos funcionários, trazendo melhores resultados. De acordo com Gomes (2003) a ergonomia objetiva sempre a melhor adequação ou adaptação possível dos objetos aos seres vivos em geral. Sobretudo no que diz respeito à segurança, ao conforto e a eficácia 
de uso ou operacionalidade dos objetos, mais particularmente nas atividades e tarefas humanas. É definida como uma ciência experimental, seus conhecimentos vem a partir de observações e experimentações em condições controladas e comprovadas pela mensuração de fenômenos, fazendo observações reais do uso de máquinas, equipamentos ou influências no ambiente de trabalho.

Segundo lida (2005), ergonomia é definida como "o desenvolvimento e aplicação da tecnologia homem/máquina, em um nível macro, ou seja, em toda a organização."

Uma empresa que envolve a ergonomia em suas decisões acaba trazendo melhorias na satisfação, segurança com redução de erros e acidentes, melhorias na saúde e produtividade na empresa como um todo. A macroergonomia tem por objetivo um estudo fundamentado na ergonomia participativa, fator este que valoriza o funcionário. Em conseqüência disso, ocorre a difusão de tais conceitos por toda a empresa e a formação da consciência ergonômica.

Com a participação dos funcionários as demandas ergonômicas são mais facilmente identificáveis em comparação à simples observação. Além disso, ao ouvir estes há uma melhor interpretação e organização do diagnóstico da empresa.

Pensar em gestão do design implica adotar ações que incluam a macroergonomia como elemento essencial e estratégico para o sucesso efetivo de um produto ou de uma organização.

\section{Caracterização da empresa}

A empresa investigada nesta pesquisa é a "Empresa A", com 40 anos de existência, atua nos segmentos de incorporação residencial, construção civil, projetos e montagens industriais. No segmento residencial o grupo esta presente em nove cidades brasileiras, em quatro estados. Atende a dois nichos de mercado, o "Premium" (público mais seletivo) e um focado para o comprador do primeiro imóvel. Mais de 120 edifícios entregues, a empresa gera mais de 650 empregos diretos, sendo que cada obra tem em torno de 150 operários.

\section{Método}

O método aplicado na pesquisa foi a Análise Macroergonômica do Trabalho com base nas informações de Bugliani (2007). Este utiliza a Apreciação Ergonômica e em seguida a Diagnose Ergonômica, envolvendo entrevista e questionários aplicados aos trabalhadores para identificação dos Itens de Demanda Ergonômica (IDE's).

Para aplicação do método foram selecionadas duas obras em execução envolvendo 15 funcionários, onde se observou várias atividades, tais como: pedreiro; pré-viga; carpinteiro; serralheiro; almoxarifado; produção de argamassa; operador de máquinas (cremalheira e "vaquinha") gesseiro e reboco.

A necessidade de uma investigação macroergonômica em relação a estas atividades deve-se ao fato de exigir um intenso serviço braçal da maioria, o que gera grande esforço do funcionário, ocasionando sérios problemas para os mesmos e, conseqüentemente, para empresa. A ferramenta do Design Macroergonômico é composta por sete etapas, onde as seis primeiras relacionam-se às coletas de dados e parâmetros do projeto e a sétima trata da projetação em si, conforme descrevem Fogliatto e Guimarães (1999) são elas:

1ㅇ) entrevista com os usuários e coletas de informações sobre as demandas ergonômicas; 
2ㅇ) priorização dos Itens de Demanda Ergonômica (IDE's) apontados pelos usuários;

3) incorporação da opinião dos especialistas nos Itens de Demanda Ergonômica complementando fatores que podem ter sido ignorados pelos usuários;

4ㅇ) aplicação de questionários para avaliar grau de satisfação dos usuários com relação aos IDE's;

5) definição dos Itens de Design (ID's), a partir dos itens que demonstraram maior índice de insatisfação;

6) proposição de melhorias em consonância com fatores como segurança, conforto, antropometria e organização do trabalho

7ㅇ) implementação do design e acompanhamentos das modificações sugeridas.

\section{Apreciação Ergonômica}

A metodologia escolhida é fundamentada no modelo de Design Macroergonômico proposto por Fogliatto e Guimarães (1999). Este defende a utilização de entrevistas e questionários com os trabalhadores para a identificação das reais demandas ergonômicas. As respostas ao serem tabeladas por meio de técnicas de estatísticas mostram os itens com maior prioridade para a proposta de mudanças no sistema. Além disso, a participação ativa dos funcionários desde o inicio do método favorece a adesão das possíveis mudanças, tanto de comportamento como de ordem físico-estrutural.

Foi realizada primeiramente a Apreciação Ergonômica de todo o ambiente por meio da imersão, onde, por observação e diálogo com o engenheiro responsável, detectaram-se diversas evidências antiergonômicas. Como já relatado, a apreciação iniciou-se diante das atividades do pedreiro, gesseiro, carpinteiro, almoxarifado entre outras atividades com máquinas. Para uma análise mais criteriosa e para evitar que pequenos detalhes não fossem percebidos inicialmente, fez-se uso de fotografias e vídeos para registro.

Com a imersão foi possível identificar algumas demandas ergonômicas no desenvolvimento das atividades. O pedreiro para assentar os tijolos assume uma postura inadequada e executa movimentos repetitivos o dia todo (Figura 1), causando dores nas costas e pelo corpo todo, além disto, o cabo de aço encontra-se fixado em lugar inadequado (Figura 2), dificultando a passagem dos materiais como cimento e tijolos para o levantamento das paredes externas, onde o funcionário tem que prender a corda de segurança nesse cabo e por ser muito próximo da parede não sente segurança alguma para executar a tarefa.

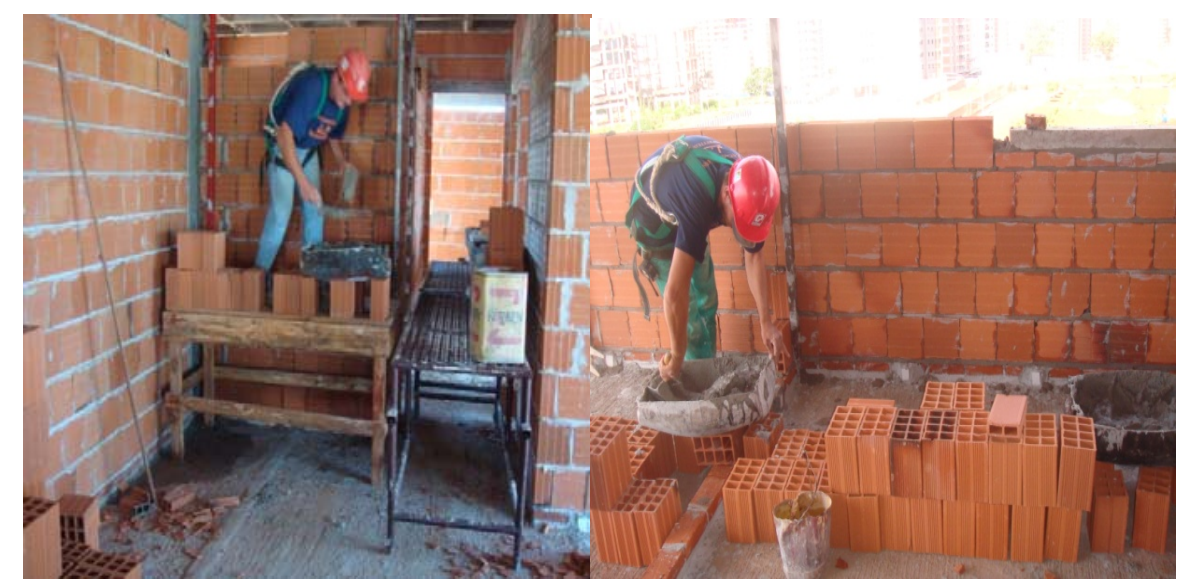

Figura 1- Pedreiro assentando tijolos-posturas inadequadas e movimentos repetitivos 
Fonte: própria

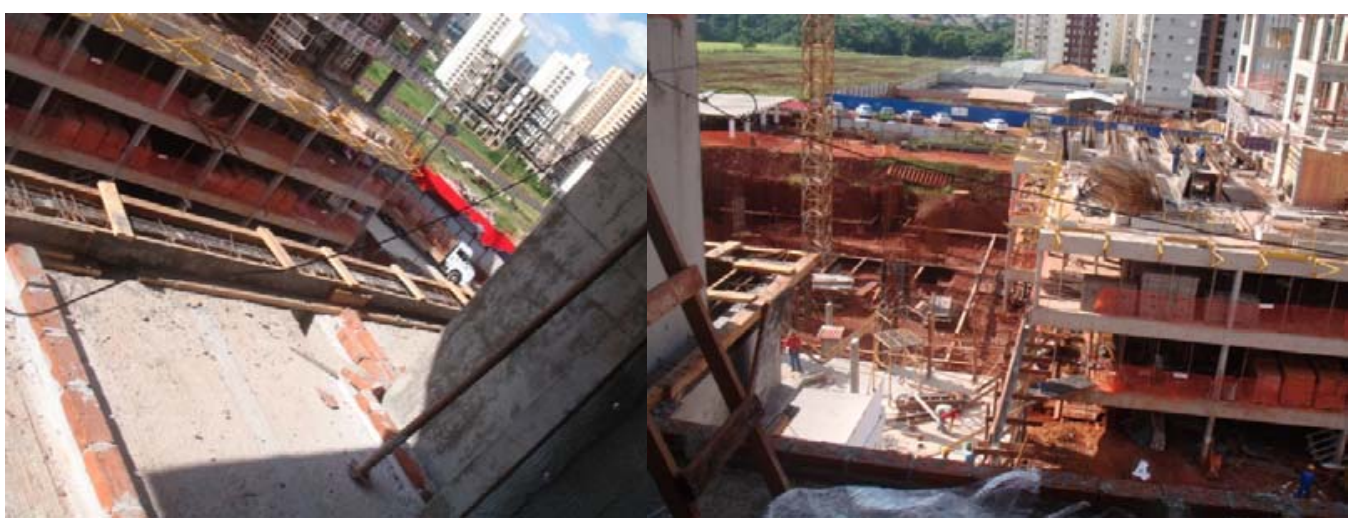

Figura 2- Cabo de aço fixado na viga lateral da parede externa

Fonte: própria

Outra atividade analisada que apresentou problemas foi da produção da pré-viga (Figura 3). Por ser executada no térreo foram apresentadas queixas quanto à exigência do uso do cinto de segurança, o grande problema indicado foi às dores nas costas, por ser um trabalho repetitivo onde o funcionário fica o tempo todo abaixando para produzir as vigas, pois as formas encontram-se rentes ao chão.

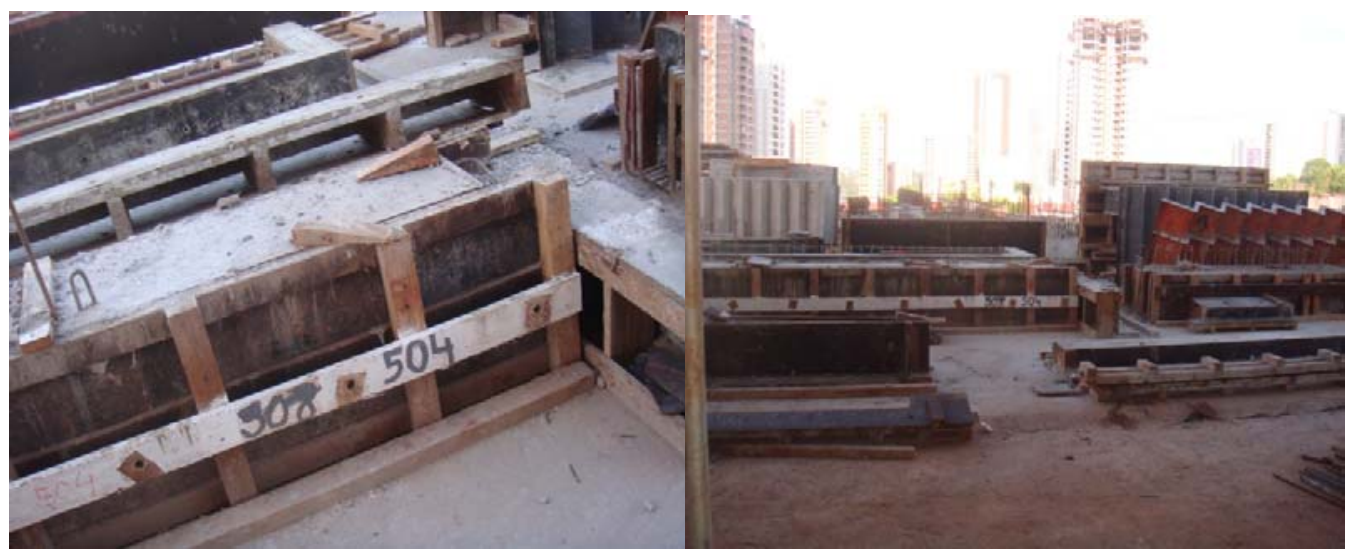

Figura 3-Formas das vigas de concreto rentes no chão

Fonte: própria

Outro ponto identificado foi à dificuldade dos funcionários de executarem todas as ordens passadas pelo encarregado da carpintaria, atrasando as tarefas a serem cumpridas durante o dia de trabalho.

No setor da serralheria foi observado o mal aproveitamento do espaço de trabalho fazendo com que os funcionários trabalhem expostos ao sol e quando chove tem que se deslocar para parte coberta do prédio em construção, além da falta de cavaletes para executarem suas tarefas ocasionando queixas, cansaço e dores pelo corpo (Figura 4). 


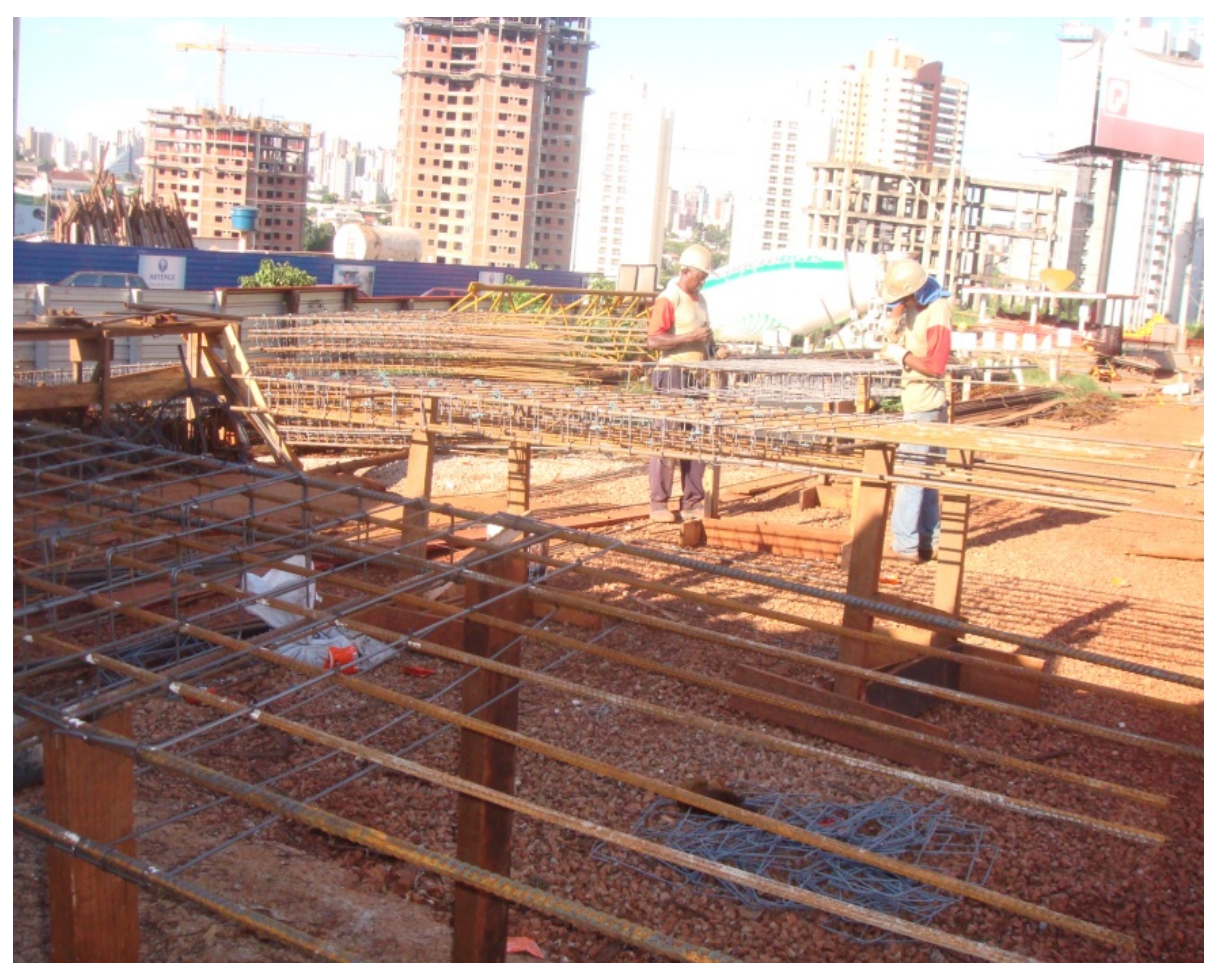

Figura 4 - Setor da serralheria

Fonte: própria

No almoxarifado foi visível o acúmulo de serviço (Figura 5), por possuir somente um funcionário que é responsável por receber, organizar as mercadorias no pátio e no almoxarifado, sendo assim o mesmo não tem tempo de organizar as mercadorias e ferramentas, perdendo muito tempo para achá-las. Além da falta de mão de obra para auxiliar no controle, o ambiente é muito quente e escuro, provocando dor de cabeça e cansaço pelo corpo (Figura 6).

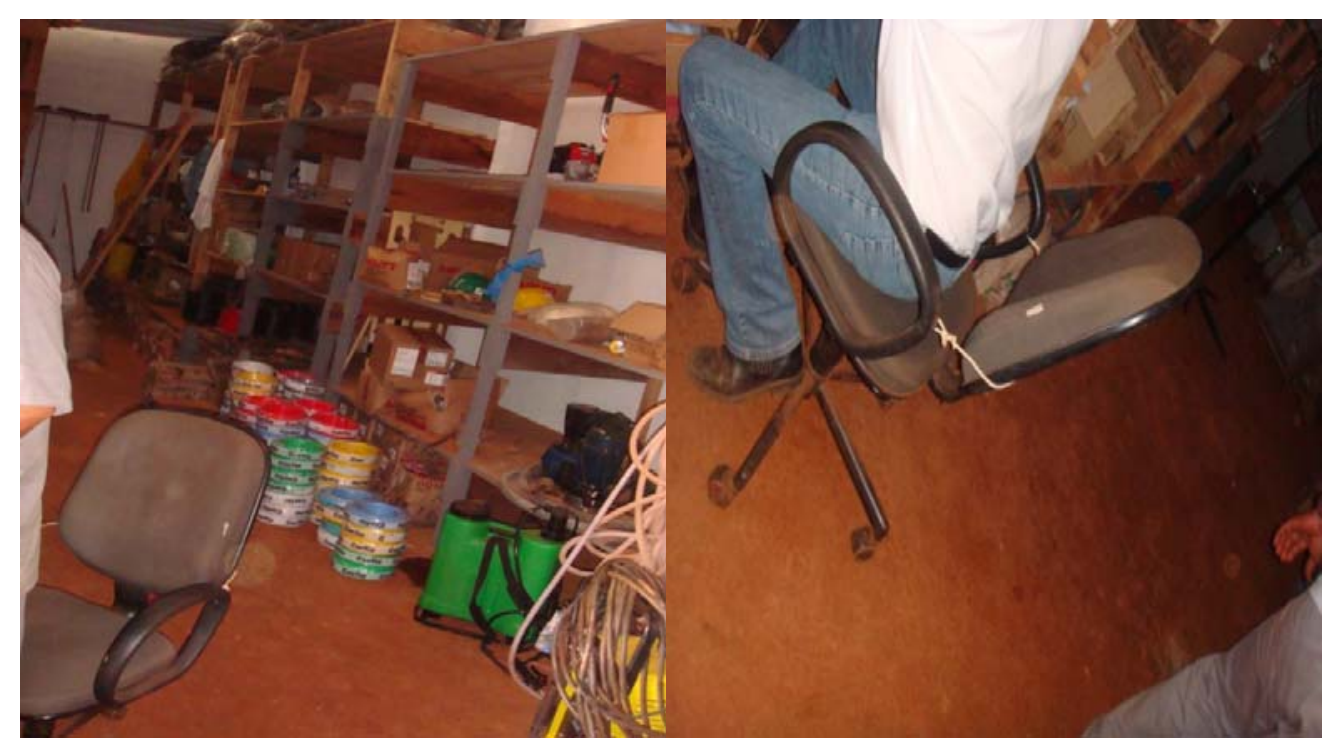

Figura 5 - Setor do almoxarifado

Fonte: própria 


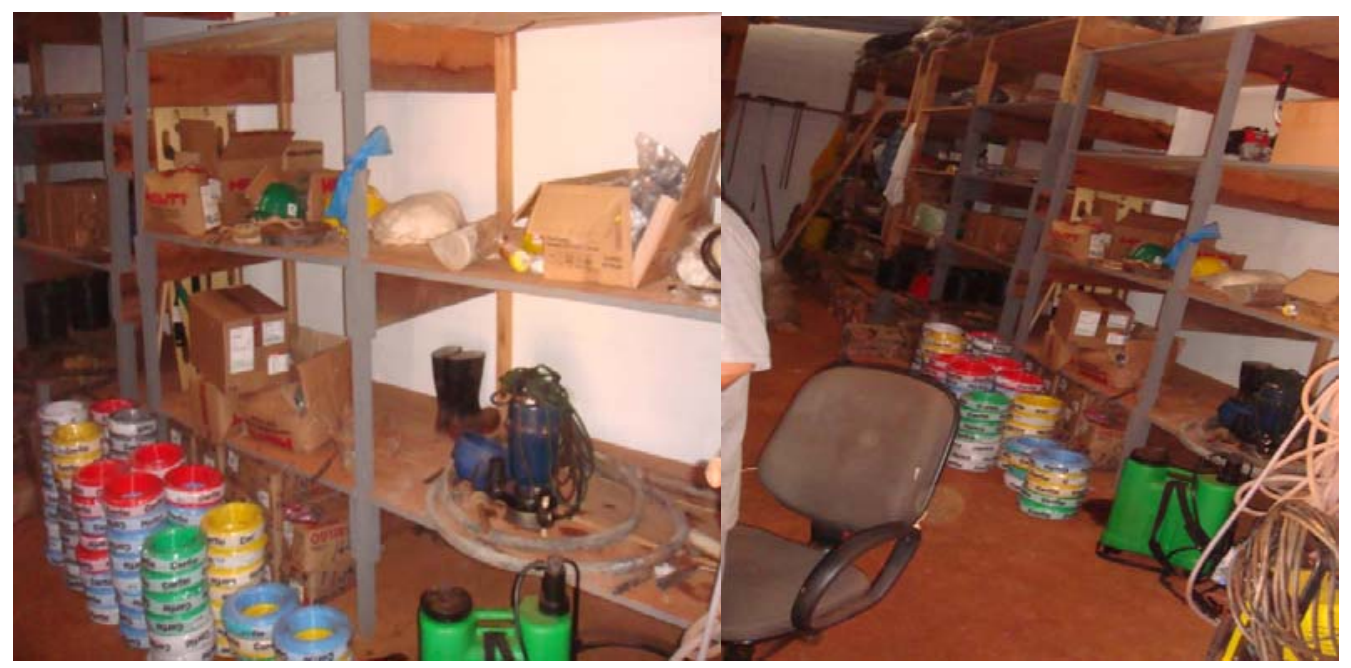

Figura 6 - Detalhe do setor do almoxarifado

Fonte: própria

No setor da produção de argamassa e operação do elevador (cremalheira) foi observado que a rampa para subir no elevador com o material que será distribuído pelos vários setores da obra é inadequada, esta se apresenta muito acentuada impossibilitando o funcionário colocar o material sozinho no elevador (Figura 7).

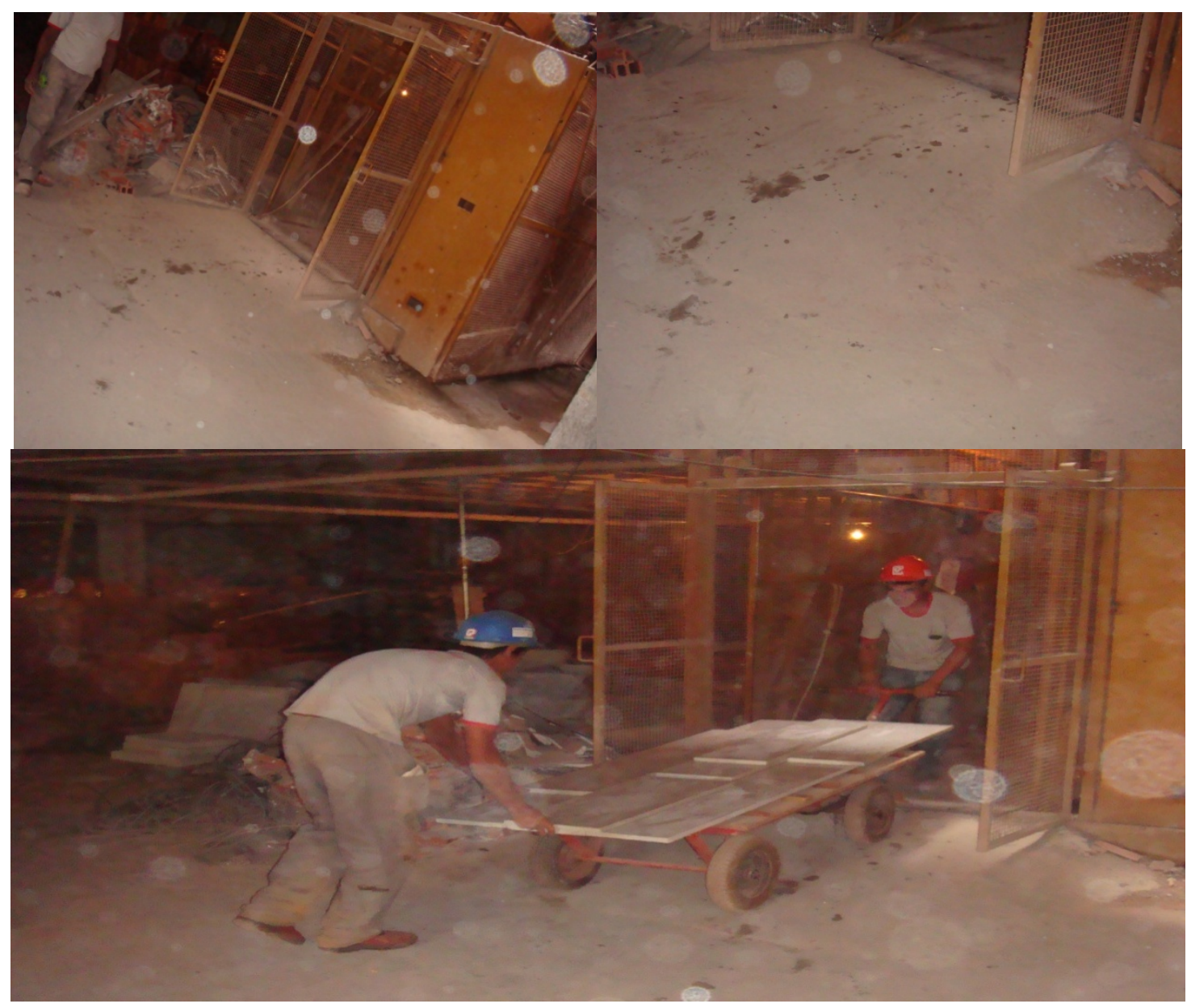

Figura 7 - Cremalheira com rampa de acesso muito acentuada

Fonte: própria 
Outro detalhe esta no elevador de apoio, a tampa não possui uma alça para evitar que o funcionário tenha que abaixar toda vez que fecha a tampa, trazendo com isso dores nas costas (Figura 8).

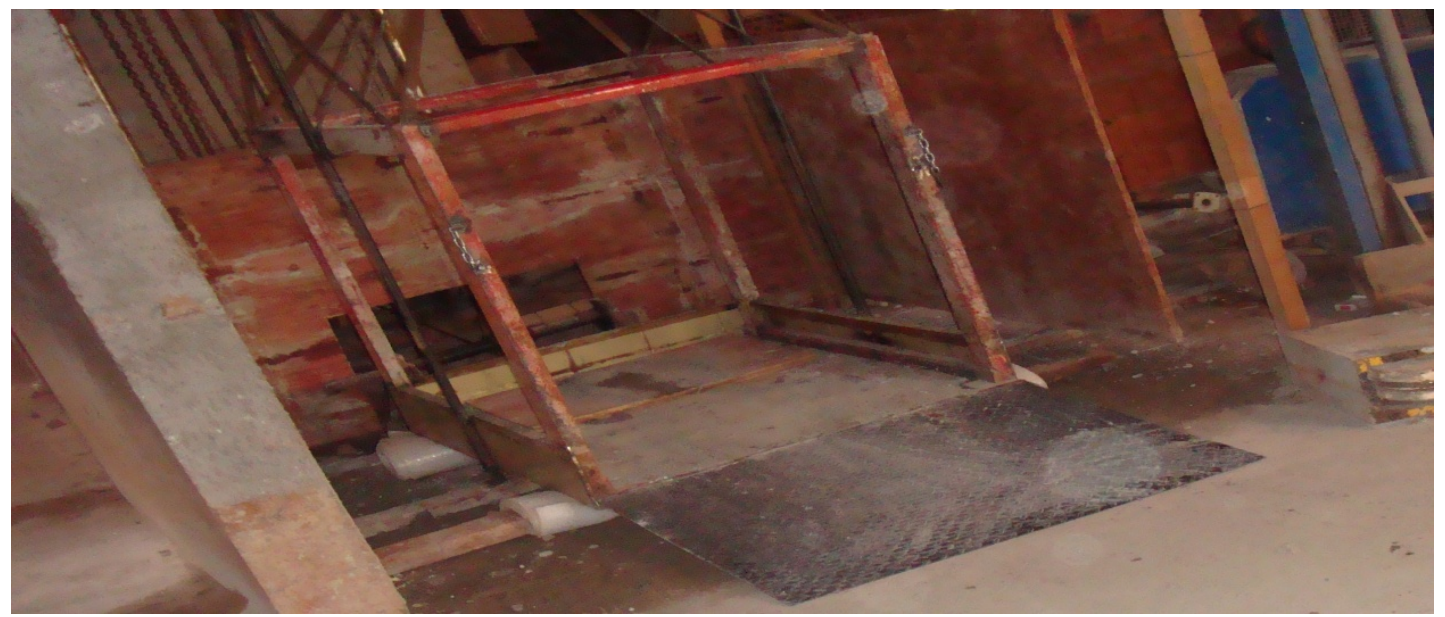

Figura 8 - Elevador de apoio carga/descarga Fonte: própria

Um dos setores observados que demonstrou maior urgência de uma intervenção ergonômica foi o operador da "vaquinha" (carrinho que carrega areia), por ser um trabalho totalmente antiergonômico (Figura 9). O funcionário precisa dispor de muita força física para executar sua tarefa de trazer a areia depositada na parte de baixo até a parte superior, para que esta seja carregada e peneirada, para isso têm que inclinar muito o corpo para desviar da viga de concreto do chão, provocando cansaço físico, dores nas costas e pernas durante e após o expediente (Figura 10).

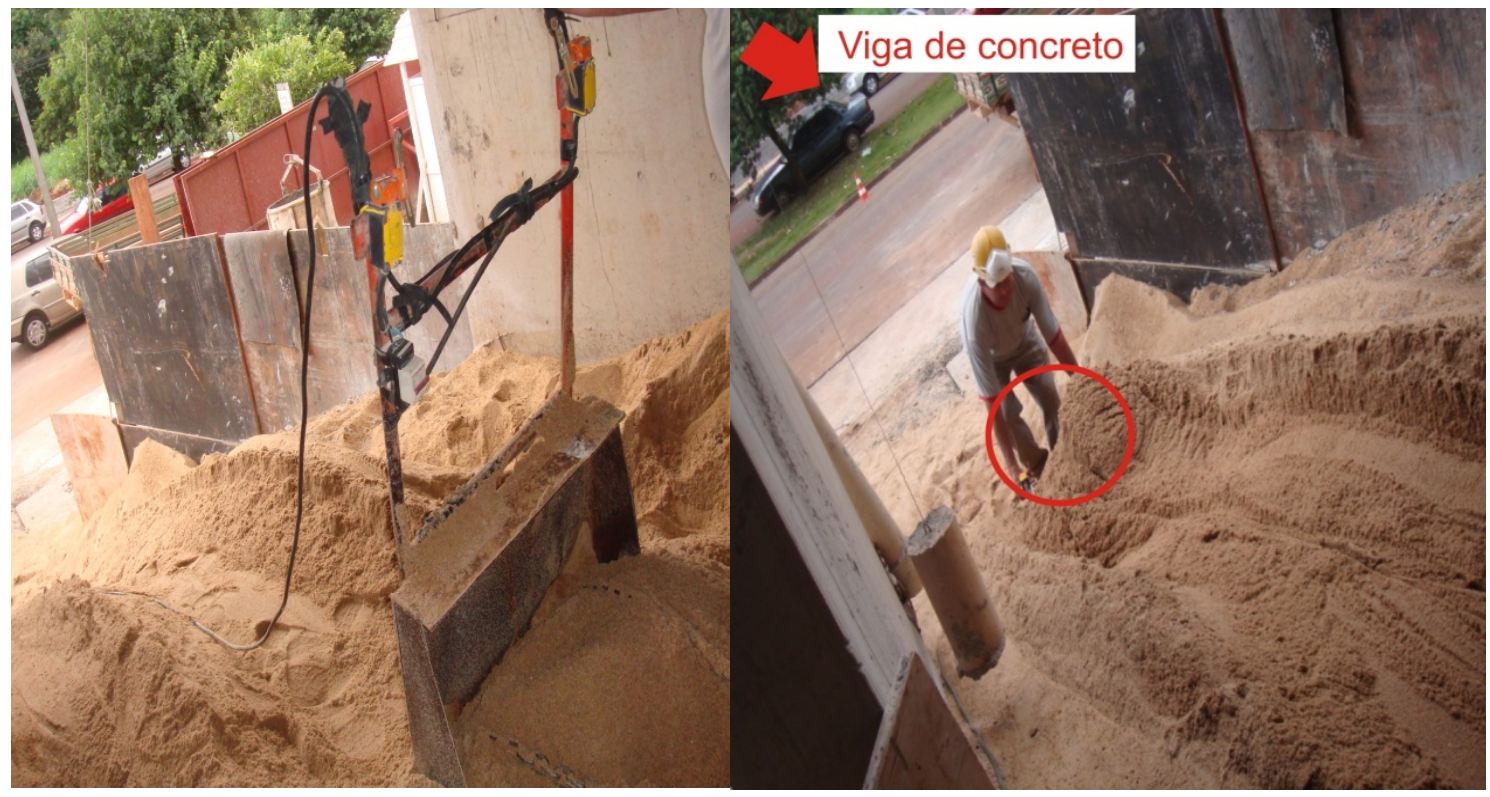

Figura 9- Operadora da "vaquinha" desviando da viga de concreto Fonte: própria 


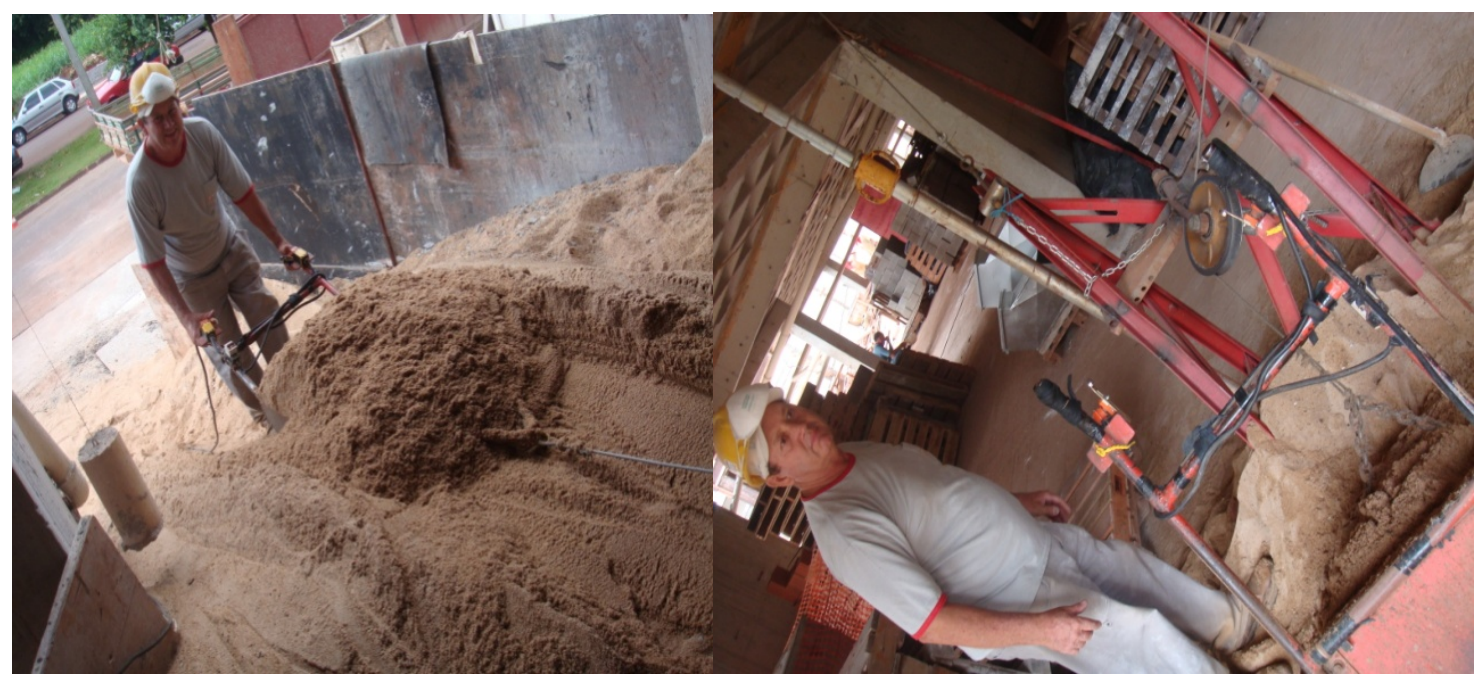

Figura 10 - Polia do cabo de aço que ajuda a puxar o carrinho Fonte: própria

$\mathrm{Na}$ atividade do gesseiro um dos pontos mais relevantes foram os movimentos repetitivos (Figura 11), onde este levanta do chão e assenta cerca de 90 a 100 placas por dia, cada placa pesa de 10 a 12 quilos, estas não podem ser menores devido ao acabamento. A junção das placas é feita com arame no teto, onde se encaixa uma a uma. Este operador sente fortes dores nos ombros durante e depois do expediente, aliviada pelo uso contínuo de medicação.

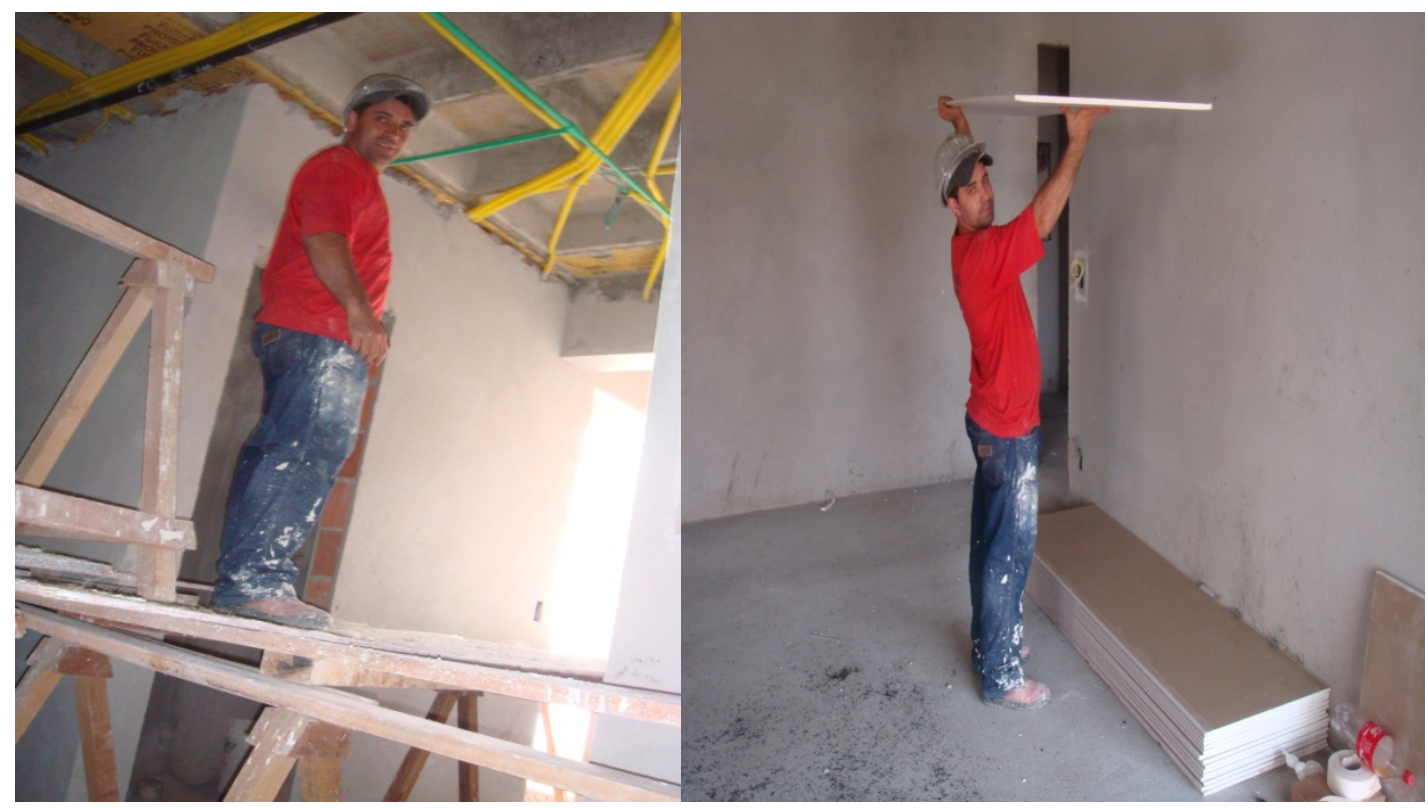

Figura11 - Movimento utilizado pelo funcionário para encaixar a placa de gesso Fonte: própria

No setor do reboco a masseira (recipiente utilizado para o deposito de argamassa) fica em uma posição muito baixa provocando dores nas costas do funcionário, por exigir movimentos repetitivos e quando têm que tampar pequenos detalhes como ponta de mangueiras ou coisas mais rápidas, não compensa manusear a bancada nos ambientes por esta ser muito grande (Figura 12). 


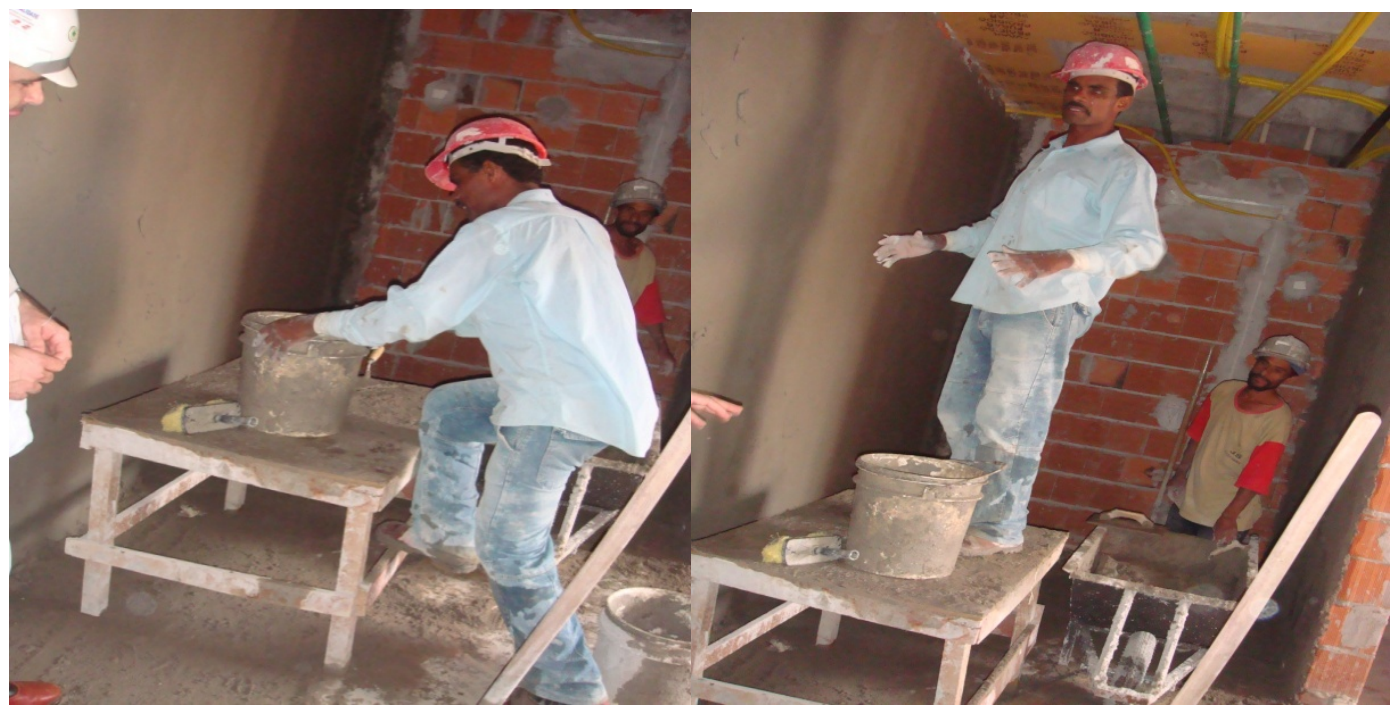

Figura 12 - Masseira utilizada pelo funcionário

Fonte: própria

\section{Diagnose Ergonômica}

\section{Entrevistas}

Conforme prevê o método da AMT, após o primeiro mapeamento por meio da Apreciação Ergonômica, partiu-se para a Diagnose Ergonômica, envolvendo as entrevistas e questionários. Por meio de uma conversa informal com os funcionários pode-se identificar os problemas mais evidentes no ambiente de trabalho. De forma individual e não induzida os 15(quinze) funcionários de todos os setores analisados citaram três fatores que os incomodam para realizar suas tarefas.

Os itens mencionados nas entrevistas foram priorizados pela ordem que foram citados, dessa forma, o primeiro fator mencionado recebeu o peso $1 / 1=1$, o segundo $1 / 2=$ 0,5 , o terceiro $1 / 3=0,33$. Com a tabulação dos dados por meio da somatória, identificaramse os Itens de Demanda Ergonômica (IDE's) de diversas categorias, tais como: ambientais, posturais, equipamentos, entre outros.

Tabela 1 - IDE'S - pedreiros (2 funcionários)

\begin{tabular}{|l|l|l|l|}
\hline & A & B & SOMATÓRIA \\
\hline $\begin{array}{l}\text { Cabo de aço sem } \\
\text { segurança }\end{array}$ & 1,0 & 0,5 & 1,0 \\
\hline $\begin{array}{l}\text { Assentar tijolos o dia } \\
\text { todo }\end{array}$ & 0,5 & 1,0 & 1,0 \\
\hline $\begin{array}{l}\text { Movimentos } \\
\text { repetitivos }\end{array}$ & 0,33 & 0,33 & 1,33 \\
\hline $\begin{array}{l}\text { Dor nas costas } \\
\text { Barulho }\end{array}$ & 0,25 & 0,33 \\
\hline \begin{tabular}{l} 
Dor no corpo \\
\hline
\end{tabular} & 0,2 & 0,25 \\
\hline
\end{tabular}


Fonte: própria

Tabela 2 - IDE'S - pré-viga (2 funcionários)

\begin{tabular}{|l|l|l|l|}
\hline $\begin{array}{l}\text { Acha que não tem } \\
\text { necessidade do uso } \\
\text { de cinto de }\end{array}$ & B & 0,5 & 1,5 \\
$\begin{array}{l}\text { segurança } \\
\begin{array}{l}\text { Cinto de segurança } \\
\text { pesado provoca dor } \\
\text { nas costas }\end{array}\end{array}$ & 0,5 & 0,33 & 0,83 \\
\hline $\begin{array}{l}\text { Forma da viga é } \\
\text { rente no chão, doem } \\
\text { as costas }\end{array}$ & 0,33 & 1,0 & 1,33 \\
\hline
\end{tabular}

Fonte: própria

Tabela 3 - IDE'S - carpintaria (encarregado-1 funcionário)

\begin{tabular}{l|l|l|} 
Passa a ordem e os & 1,0 \\
funcionários não & \\
$\begin{array}{l}\text { executam no tempo } \\
\text { certo }\end{array}$
\end{tabular}

Fonte: própria

Tabela 4 - IDE'S - serralheiro (2 funcionários)

\begin{tabular}{|l|l|l|l|}
\hline $\begin{array}{l}\text { Trabalho exposto ao } \\
\text { sol }\end{array}$ & A & B & SOMATÓRIA \\
\hline $\begin{array}{l}\text { Falta de cavalete } \\
\text { Mal }\end{array}$ & 0,33 & 1,0 & 2,0 \\
\hline $\begin{array}{l}\text { dimensionamento do } \\
\text { espaço de trabalho }\end{array}$ & 0,5 & 0,5 & 0,88 \\
\hline \begin{tabular}{l} 
Fonte: própria \\
\hline
\end{tabular} & 0,33 & 0,88 \\
\hline
\end{tabular}

Tabela 5 - IDE'S - almoxarifado - (1 funcionário)

\begin{tabular}{l|l|}
\hline Falta tempo para organizar & A \\
\hline Falta Mão de obra & 0,5 \\
\hline $\begin{array}{l}\text { Perde muito tempo para } \\
\text { achar as coisas }\end{array}$ & 0,33 \\
\hline
\end{tabular}




\begin{tabular}{|l|l|}
\hline Muito calor & 0,25 \\
\hline Cansaço no corpo & 0,2
\end{tabular}

Fonte: própria

Tabela 6 -IDE'S - argamassa/cal/cimento (1 funcionário)

A

Cremalheira (elevador) com 1,0

rampa muito acentuada

Precisa de mais funcionários 0,5

para entrar com o carrinho

no elevador

Fonte: própria

Tabela 7 - IDE'S - operadora do elevador (2 funcionários)

\begin{tabular}{l|l|l|l|}
\hline \multicolumn{1}{|c|}{ A } & B & SOMATÓRIA \\
\hline $\begin{array}{l}\text { Precisa de mais } \\
\text { funcionários para } \\
\text { colocar o material no } \\
\text { elevador }\end{array}$ & 1,0 & 2,0 \\
\hline $\begin{array}{l}\text { Tem que abaixar para } \\
\text { fechar a tampa }\end{array}$ & 0,5 & 0,5 & 1,0 \\
\hline
\end{tabular}

Fonte: própria

Tabela 8 - IDE'S-operador de vaquinha (1 funcionário)

\begin{tabular}{|l|l|} 
& A \\
\hline $\begin{array}{l}\text { Inclina muito o corpo para } \\
\text { desviar o carrinho da viga }\end{array}$ & 1,0 \\
\hline $\begin{array}{l}\text { Dor nas costas } \\
\text { Movimento repetitivo }\end{array}$ & 0,5 \\
\hline
\end{tabular}

Fonte: própria

Tabela 9 - IDE'S - gesseiro (1 funcionário)

\begin{tabular}{|l|l|}
\hline Movimento repetitivo & A \\
\hline Dor nos ombros & 1,0 \\
\hline
\end{tabular}

Fonte: própria 
Tabela 10 - IDE'S - reboco (2 funcionários)

\begin{tabular}{l|l|l|l|}
\hline & A & B & SOMATÓRIA \\
\hline Masseira baixa & 1,0 & & 1,0 \\
\hline $\begin{array}{l}\text { Dor nas costas } \\
\begin{array}{l}\text { Difícil manusear a } \\
\text { bancada para } \\
\text { execução de coisas } \\
\text { mais rápidas }\end{array}\end{array}$ & 0,5 & 1,0 & 1,0 \\
\hline
\end{tabular}

Fonte: própria

A partir destes resultados elaborou-se um questionário, onde todos deveriam demonstrar seu grau de satisfação quanto aos itens de demanda ergonômica obtidos na entrevista anterior e o levantamento de informações sobre possíveis dores ou mal estar.

Dos 15 funcionários obteve-se a resposta apenas de 13 de todos os setores analisados. As questões de satisfação foram elaboradas através de uma escala de avaliação contínua de $15 \mathrm{~cm}$ sugerida por Stone et al. (apud SILVA et al., 2002). O entrevistado marca na escala um ponto de acordo com sua satisfação, quanto mais próximo dos $15 \mathrm{~cm}$ mais satisfeito, e quanto mais próximo do $0 \mathrm{~cm}$, mais insatisfeito. 0 resultado final em relação a cada IDE'S é obtido pela média aritmética.

Foi questionado sobre possíveis desconfortos ou dores, tempos de pausa no expediente, e ainda foi aberto espaço para opinião ou comentários sobre o trabalho. 


\section{Itens de Demanda Ergonômica}

Número de tarefas

Tarefas exigidas

Aplicação de gesso

Espaço disponível

Masseira

Dimensões do local de trabalho

Cinto de segurança

Elevador

Ferramentas

Cremalheira

1,65

Cabo de aço

1,46

Fabricação das vigas de concreto

1,15

Operar "vaquinha" | 0,4

(Insatisfação)

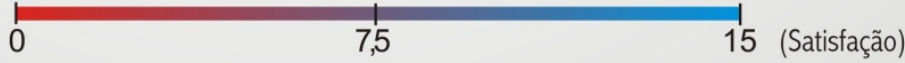

10,25

8,9

8,9

8,33

7,07

5,46

5,25

4,47

Figura 13-Gráfico com resultados dos questionários

Fonte: própria

Tabela 11 - Dores em regiões do corpo por funcionários durante o expediente

\begin{tabular}{|l|l|}
\hline Dores durante o expediente & Q.Q de funcionários \\
\hline Braços & 6 \\
\hline Pernas & 9 \\
\hline Ombro & 5 \\
\hline Região Lombar & 10 \\
\hline Cabeça & 4 \\
\hline
\end{tabular}

Fonte: própria

Tabela 12 - Dores em regiões do corpo por funcionários após o expediente Dores depois do expediente Q.Q de funcionários Braços 2 


\begin{tabular}{|l|l|}
\hline Pernas & 8 \\
\hline Ombro & 2 \\
\hline Região Lombar & 10 \\
\hline Mãos & 1 \\
\hline Fonte: própria & \\
\hline
\end{tabular}

A partir dos aspectos diagnosticados na AMT será indicado as sugestões macroergonômicas a seguir.

\section{Sugestões Macroergonômicas}

Com base nas respostas obtidas, assim como nas observações realizadas no local de trabalho, pôde-se constatar o grau de dificuldade na execução das tarefas e dores na região lombar, ombro, pernas e cansaço excessivo, por movimentos repetitivos e posturas inadequadas.

Sabe-se que os trabalhos executados com contração prolongada de músculos com esforço repetitivo tornam-se prejudiciais ao metabolismo dos tecidos, principalmente tendões, levando a quadro crônicos de dor e incapacidade. Para Melzer (2007) as lesões por esforço repetitivo e DORT Doenças Osteomusculares Resultantes do Trabalho, trazem conseqüências que comprometem a qualidade de vida de um indivíduo, movimentos incorretos na execução das tarefas sobrecarrega a coluna, conseqüentemente provoca dores. A má postura causa fadiga e é uma das causas da baixa motivação, diminui a produtividade do funcionário, se houver a prevenção consegue-se diminuir os custos, aumentar a produtividade, a motivação, trazendo benefícios tanto para o funcionário como para a empresa. As tendinites de ombro e punho, inflamações dos tendões musculares como foi indicado no setor do gesso ocorre devido a ombros elevados por muito tempo, os braços ficam acima do nível dos ombros e os movimentos da musculatura contraída e repetida provoca dores fortes no local.

Os funcionários desta empresa não recebem nenhuma orientação ou treinamento com o objetivo de adotarem uma postura correta durante suas atividades, e com o decorrer do tempo acaba acarretando problemas para os trabalhadores e conseqüentemente para empresa. Para aliviar as dores alguns funcionários mencionaram que fazem uso de medicação constantemente. As queixas de dores nas costas citadas são resultantes de um posto de trabalho que não oferece condições ideais para uma jornada de oito horas. Segundo Abrantes (2004) a lombalgia (dor na região lombar) é no Brasil, a segunda causa de afastamentos do trabalho e a terceira em aposentadorias. Os custos financeiros e humanos dos problemas relacionados à coluna são muito altos.

De acordo com essas observações é clara a necessidade de um fisioterapeuta do trabalho na empresa. Segundo Militão (2001), a ginástica laboral é uma atividade física praticada no ambiente do trabalho durante o expediente a qual visa promover a saúde dos funcionários e evitar lesões por esforços repetitivos e doenças ocupacionais.

A ginástica laboral além de ser um exercício físico, consiste em alongamento, relaxamento muscular e flexibilidade das articulações. É uma atividade coletiva e moldada de acordo com a função exercida pelo funcionário por um breve tempo de 10 a 15 minutos. Esta proporciona ganhos psicológicos, diminuição do estresse e aumento de concentração, motivação e auto-estima dos funcionários. É preciso que haja uma conscientização de cada indivíduo, desde engenheiros até os demais membros da organização para a implantação e eficiência desta nova prática nos setores estudados nesta pesquisa. Para isto sugerem-se 
treinamentos anteriores à implementação da proposta, com palestras ministradas por profissionais da área.

No setor dos pedreiros além da indicação da ginástica laboral foi sugerida a mudança da fixação do cabo de aço para a viga superior em dois metros de altura com um metro de recuo, isso facilitaria a locomoção do funcionário e os manuseios dos materiais por ele utilizados na execução da parede externa no ambiente de trabalho, além de proporcionar maior segurança. Vale salientar que esta sugestão foi definida juntamente com os funcionários.

No setor da pré-viga que se localiza no térreo observou-se que o uso do cinto de segurança realmente pode ser dispensado evitando dores e incômodos aos funcionários, para solucionar os problemas relacionados às dores nas costas, foi sugerido pelos funcionários o uso de cavaletes fixos para suspender as formas, segundo os próprios funcionários à altura ideal seria de $50 \mathrm{~cm}$ para os cavaletes que somados à altura da forma chegaria aproximadamente a $90 \mathrm{~cm}$. De acordo com Abrantes (2004) as dimensões da bancada recomendadas para executar um trabalho pesado em pé, está entre 70 a $90 \mathrm{~cm}$ de altura, considerando a altura dos cotovelos em $104,5 \mathrm{~cm}$, dessa maneira os funcionários não terão que se abaixar para confeccioná-las. Para Nascimento e Moraes (2000), os projetos inadequados de máquinas, assento ou bancadas de trabalho obrigam o trabalhador a usar posturas inadequadas que mantidas por muito tempo, podem provocar fortes dores localizadas naquele conjunto de músculos solicitados para conservação da postura.

No setor de carpintaria a dificuldade apresentada pelo encarregado foi o não cumprimento das tarefas sugeridas por ele para o dia de trabalho. Recomendou-se o uso de um mural com a programação das tarefas diárias expostas na parede da oficina do setor com o nome do respectivo funcionário encarregado de executá-la no dia.

No setor da serralheria foram sugeridas pequenas mudanças como prolongar a cobertura para evitar que trabalhem expostos ao sol, dimensionar melhor o espaço de trabalho e aumentar o número de cavaletes. Segundo lida (2005) o clima, principalmente a temperatura e a umidade ambiental, influi diretamente no desempenho do trabalho humano. Estudos comprovam essas influências, tanto sobre a produtividade, como sobre os riscos de acidentes. Segundo Abrantes (2004) dentro do contexto de Ergonomia, como "Ciência do Conforto" que busca o ponto ótimo entre conforto e produtividade, deve levar em consideração alguns fatores que, com maior ou menor intensidade, interferem no rendimento do funcionário. A temperatura é um dos fatores de desconforto ambiental que pode interferir no desempenho, humor e bem-estar do funcionário.

Apesar deste item não estar atrelado ao Design, sugere-se que no almoxarifado seja terceirizado o serviço de organização do estoque para facilitar a manutenção pelo funcionário encarregado, a partir de feedbacks com o responsável pelo setor. De acordo com lida (2005) um posto de trabalho com restrição de espaço tende causar estresse, além de reduzir a velocidade e aumentar os erros. Para amenizar o calor indica-se colocar em prática o projeto de isolante térmico com caixa tetra Pak, além de pelo menos um ventilador.

De acordo com Abrantes (2004) o risco de acidentes e lesões de coluna e musculatura já é grande na movimentação dos materiais, este risco aumenta consideravelmente quando essas cargas precisam ser transportadas em rampas ou escadas. Para solucionar o problema dos funcionários da argamassa e operadores da cremalheira o mais indicado seria prolongar e reduzir a inclinação da rampa de acesso ao elevador, isto amenizaria o esforço feito pelos funcionários para carregar a cremalheira, onde somente um funcionário conseguiria fazer o serviço. 
No elevador de apoio indica-se colocar uma alça, assim como na cremalheira, isto facilitaria levantar e abaixar a tampa do elevador sem que o funcionário tivesse que se abaixar.

O operador da "vaquinha" é o setor com maior urgência ergonômica, considerando o grande esforço físico que o funcionário necessita para cumprir sua tarefa. De acordo com Abrantes (2004) cada operador possui suas características próprias e, sempre que possível os postos de trabalho devem ser adaptados a essas características. As tarefas a serem realizadas e os equipamentos usados devem ser projetados para o operador, em vez de forçar a adequação do operador aos mesmos, pois lesões e perdas de produtividade são comuns quando o elemento humano é obrigado a se adequar ao posto e ao sistema de trabalho. A sugestão seria modificar a máquina instalando a polia do cabo mais alta, onde o próprio cabo tenderia desviar a vaquinha da viga no chão, puxando-a para cima amenizando desta maneira o grande esforço exigido pelo funcionário.

No setor do gesseiro indica-se a contratação de um auxiliar para dividir a carga de trabalho no levantamento das placas de gesso, apesar deste item não estar atrelado ao design, sugere-se esta contratação a partir de feedbacks com o responsável pelo setor.

No setor do reboco para facilitar o trabalho e evitar fortes dores nas costas levantouse a necessidade de uma bancada extra para depositar a massa, atendendo as exigências ergonômicas, sugere-se que essa bancada tenha $1,50 \mathrm{~m}$ de altura, valor este sugerido pelos funcionários, nesta posição a bancada ficará posicionada a $95 \mathrm{~cm}$ acima do andaime, onde o funcionário permanece. Segundo Abrantes (2004) a altura de bancada para trabalho leve deve ser de 85 a $95 \mathrm{~cm}$, considerando o plano do cotovelo em 104,5 cm. Outra sugestão seria ter uma bancada menor, mais fácil de manusear nos ambientes, usada para pequenos e rápidos serviços como tampar pontas de mangueira.

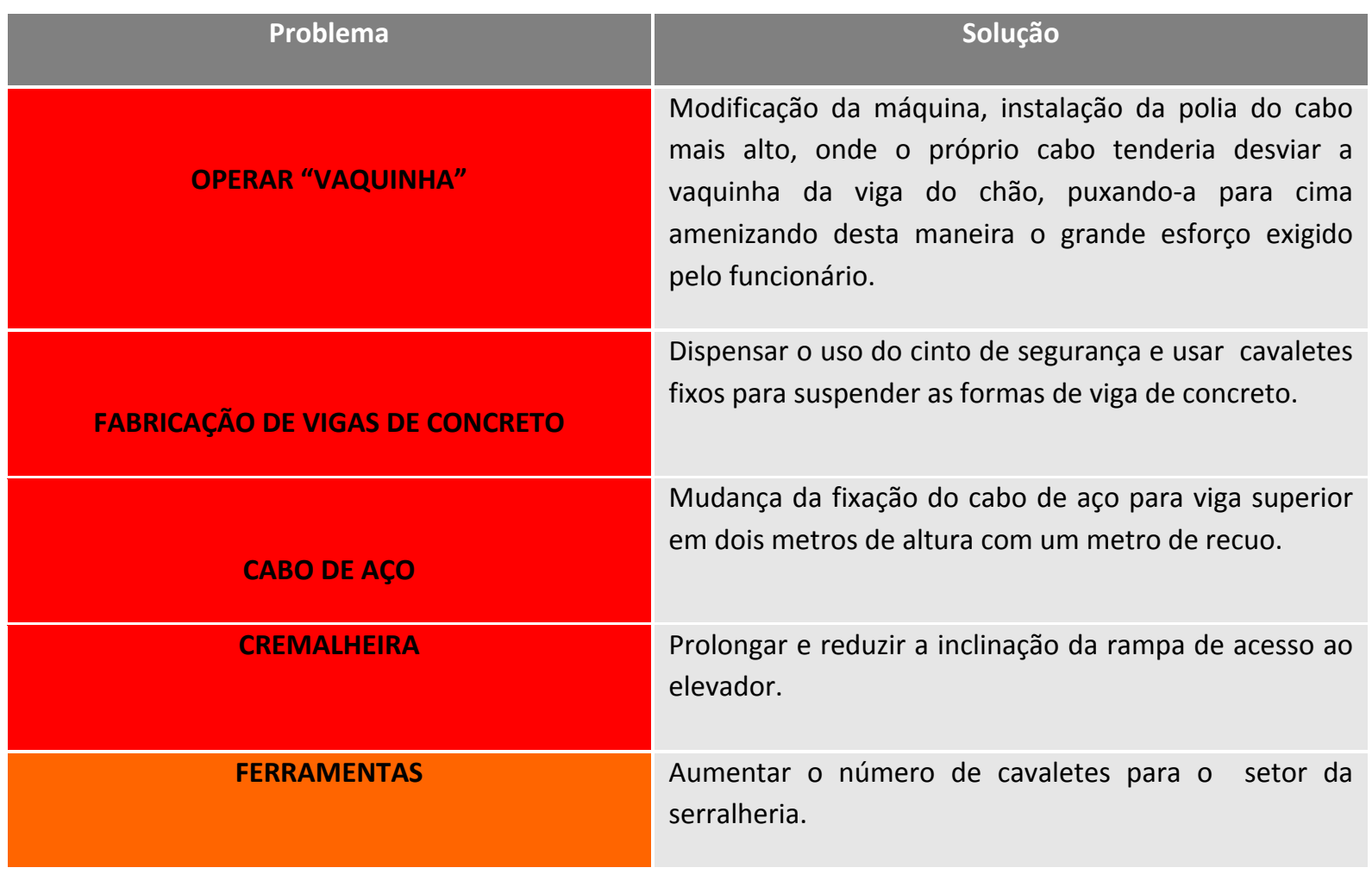




\begin{tabular}{|c|c|}
\hline ELEVADOR & Instalar uma alça no elevador de apoio. \\
\hline CINTO DE SEGURANÇA & $\begin{array}{l}\text { Dispensar o uso do cinto de segurança no setor de pré- } \\
\text { viga, por localizar-se no térreo. }\end{array}$ \\
\hline DIMENSÕES DO LOCAL DE TRABALHO & $\begin{array}{l}\text { Dimensionar melhor o espaço de trabalho na } \\
\text { serralheria e no almoxarifado. }\end{array}$ \\
\hline MASSEIRA & $\begin{array}{l}\text { Necessário uma bancada extra com } 1,50 \mathrm{~m} \text { para } \\
\text { depositar a massa e uma menor de fácil manuseio para } \\
\text { pequenos e rápidos serviços. }\end{array}$ \\
\hline ESPAÇO DISPONÍVEL & $\begin{array}{l}\text { Prolongar a cobertura, dimensionar melhor o espaço no } \\
\text { setor da serralheria. }\end{array}$ \\
\hline APLICAÇÃO DO GESSO & Contratação de um auxiliar. \\
\hline TAREFAS EXIGIDAS & $\begin{array}{l}\text { Utilizar um mural com programação das tarefas diárias } \\
\text { exposto na parede da oficina do setor com o nome do } \\
\text { respectivo funcionário encarregado de executá-la no } \\
\text { dia. }\end{array}$ \\
\hline NÚMERO DE TAREFAS & $\begin{array}{l}\text { Terceirizar o serviço de organização do estoque do } \\
\text { almoxarifado para facilitar a manutenção pelo } \\
\text { funcionário encarregado. }\end{array}$ \\
\hline
\end{tabular}

Quadro 1 - Síntese dos problemas e soluções a partir do método da AMT dos setores.

Fonte: própria

\section{Conclusão}

A aplicação do método da Análise Macroergonômica do Trabalho (AMT) nas empresas, parte do princípio que um programa de ergonomia deve identificar, monitorar e alterar qualquer situação que possa comprometer a qualidade de vida no trabalho.

Por meio da pesquisa participativa com relatos dos funcionários, puderam-se identificar os mais graves problemas dentro dos setores e atividades analisadas, o que era objetivo principal desta pesquisa. Quanto aos problemas físico-ambientais foram sugeridas ações que envolveram desde simples orientações focadas na conscientização dos funcionários em relação a determinados fatos, até modificações de máquinas e equipamentos; quanto aos problemas organizacionais foram indicados treinamentos com palestras ministradas por profissionais da área, e por fim quanto ao único problema de relacionamento foi sugerido o uso de um mural com a programação das tarefas diárias, expostas na parede da oficina do setor com o nome do respectivo funcionário encarregado de executá-la no dia.

Não resta dúvida que as empresas que utilizarem um enfoque macroergonômico no seu planejamento, conseguirão proporcionar aos seus funcionários um trabalho mais humano e, conseqüentemente, benefícios às mesmas obtendo maior sucesso em seus produtos e serviços. 
Ao fim desta pesquisa é possível afirmar que a macroergonômia apresenta-se como um método altamente eficiente para implantar um programa ergonômico na empresa, efetuando um trabalho de prevenção evitando patologias, melhorando a qualidade de vida, trazendo maior segurança, conforto e satisfação no processo laboral. Vale lembrar que a Macroergonomia, por meio do método da AMT, pode contribuir consideravelmente para a implantação da Gestão do Design na empresa, a partir do diagnóstico fidedigno aos reais problemas presentes na mesma e muitas vezes ocultos.

\section{Referências}

ABRANTES, Antonio Francisco. Atualidades em ergonomia: logística, movimentação de materiais engenharia industrial. São Paulo: IMAM, 2004.

BUGLIANI, R.de O. Macroergonômia: um panorama do cenário brasileiro. 2007. Dissertação (Mestrado em Design) - Faculdade de Arquitetura, Artes e Comunicação, Universidade Estadual Paulista "Júlio de Mesquita Filho", Bauru, 2007.

BROWN, Ogden Jr. The development and domain of participatory ergonomics. In: INTERNATIONAL ERGONOMICS ASSOCIATION WORLD CONFERENCE, 1995, Rio de Janeiro.

FOGLIATTO, Flávio; GUIMARÃES, Lia B. M. Design macroergonômico: uma proposta metodológica para projeto de produto. Produto \& Produção, Porto Alegre, v.3, n.3, 1999.

GOMES FILHO, João. Ergonomia dos objetos: sistema técnico de leitura ergonômica. São Paulo: Escritura, 2003.

GUÉRIN, F. Compreender o trabalho para transformá-lo: a prática da ergonomia. Tradução Giliane M. J. Ingratta; Marcos Maffei. São Paulo: E. Blücher, 2001.

HENDRICK, H. Macroergonomics: a new approach for improving productivity, safety, and quality of work life. In: LATIN AMERICAN CONGRESS OF ERGONOMICS, 2, 1993, Florianópolis. p. 39-58.

IIDA, Itiro. Ergonomia: projeto e produção. 2. ed. São Paulo: E. Blücher, 2005.

KROEMER, K. H. E. Manual de ergonomia: adaptando o trabalho ao homem. Tradução Lia Buarque de Macedo Guimarães. 5. ed. Porto Alegre: Bookman, 2005.

MILITÃO, Angeliete Garcez A influência da ginástica laboral para a saúde dos trabalhadores e sua relação com os profissionais que a orientam. 2001. Dissertação (Mestrado em Engenharia de Produção) - Universidade Federal de Santa Catarina, Florianópolis.

MARTINS, Rosane Fonseca de Freitas; MERINO, Eugenio Andrés Diaz. Gestão de design como estratégia organizacional. Londrina: EDUEL, 2008. 
MELZER, Adriana Cristina de Souza. Fatores de risco físicos e organizacionais associados a distúrbios osteomusculares relacionados ao trabalho na indústria têxtil. Revista de Fisioterapia e Pesquisa, v. 15, n. 1, p. 19-25, 2008.

NASCIMENTO, Nivalda Marques; MORAES Roberta de Azevedo Sanches. Fisioterapia nas Empresas. Rio de Janeiro: Taba Cultural, 2000.

WOLF, Brigitte. O design management como fator de sucesso. Florianópolis: ABIPITIPrograma Catarinense de design, 1998. 